Article

\title{
Freedom, Commerce, Bodies, Harm: The Case of Backpage.com
}

\author{
Elizabeth Swanson \\ Arts and Humanities Division, Babson College, MA 02457 Wellesley, USA; E-Mail: eswanson@babson.edu
}

Submitted: 23 February 2017 | Accepted: 4 May 2017 | Published: 23 June 2017

\begin{abstract}
This article situates lawsuits against Backpage.com in the context of changing laws and norms of sexual commerce and trafficking, and of evolving legal interpretations of Section 230 of the Communications Decency Act. Section 230 has been used repeatedly to shield internet service providers such as Backpage.com from liability for content generated by third parties that has led to criminal harm to others; in this case, the trafficking and commercial sexual exploitation of minors. Moving to a critique of the law as at times grievously detached from the realities it addresses, I compare the legal strategies and decisions in three prominent cases brought against Backpage.com in St. Louis, Tacoma, and Boston, respectively. This critique identifies the evacuation of gendered bodies and the harm done to them from the court opinions as an example of what Robert Cover has called the "interpretive violence" of the law, and of the judges who interpret and dispense it. I conclude by calling for courts and Congress to act together to disrupt the accumulation of interpretive precedent favoring freedom of commerce and speech over the protection of bodies from harm.
\end{abstract}

\section{Keywords}

Backpage.com; Communications Decency Act; human trafficking; legal theory; minors; sex trafficking; sexual commerce

\section{Issue}

This article is part of the issue "Perspectives on Human Trafficking and Modern Forms of Slavery", edited by Siddharth Kara (Harvard Kennedy School, USA).

(C) 2017 by the author; licensee Cogitatio (Lisbon, Portugal). This article is licensed under a Creative Commons Attribution 4.0 International License (CC BY).

\section{"Legal interpretation takes place in a field of pain and death." Robert Cover (1986)}

\section{Introduction}

A simple internet search for information about Backpage.com CEO Carl Ferrer yields little. Based on the results, it would seem that Ferrer's life began in 2004, when he teamed up with New Times Media principles Michael Lacey and James Larkin to launch Backpage.com, the world's largest online purveyor of "adult services" advertisements, as a strategic response to the market-driven migration of classified ads from print to internet vehicles. Since then, Ferrer's persona is best grasped through the phrase "no comment," repeated on camera and in print to reporters, judges, and legislators seeking his response to charges of trafficking adults and minors on Backpage.com-charges arising from law enforcement, trafficking victims and their amici in state courts around the country, and even the Senate Permanent Subcommittee on Investigations. Like other powerful people charged with unethical or criminal behavior, Ferrer's evasion of even the question of the charges only added to the sense of invulnerability attached to his image as an international corporate CEO-that is, until his arrest in October 2016 on felony charges of pimping and conspiracy, at which point his mug shot became the primary image radiating from internet search engines.

This article considers the role of the law in producing the gap between the Ferrer empowered to repel inquiry with the phrase "no comment" and the Ferrer compelled to respond to allegations as a criminal defendant in a court of law-in other words, between Ferrer the CEO and Ferrer the alleged pimp and trafficker. The crux of the matter-justice and redress for minors trafficked through advertisements posted on Backpage.com-remains stuck in that breach, reminding us that the law is a flexible instrument, a power-tool as likely to preclude as to produce justice. What lies in the 
space between justice and its foreclosure is precisely the paradox that legal scholars Robert Cover and Colin Dayan have identified as the violence of the law, wielded purposefully or not by legislators (makers of the law) and judges (interpreters and distributors of the law). If the law came into being as an instrument to prevent the commission of violence, and to protect the weak from the strong, then, as Colin Dayan (2011) writes, "legal reasoning [must be made] as vital as the lives of persons lethally affected by it" (p. x).

I take up Dayan's challenge here, commencing by briefly situating suits against Backpage.com within the context of changing laws and norms of sexual commerce and trafficking, and of evolving legal interpretations of Section 230 of the Communications Decency Act (CDA), which has been evoked repeatedly to shield internet service providers such as Backpage.com from liability for content generated by third parties that has led to criminal harm to others. Moving to a critique of the technology of law as at times grievously detached from the realities it addresses and the spirit of justice it is meant to bring into being, I compare the legal strategies and decisions in three prominent cases brought against Backpage.com in St. Louis, Tacoma, and Boston, respectively, identifying the evacuation of gendered bodies and the harm done to them from the court opinions as an example of the "interpretive violence" of the law, and calling for courts and congress to act together to disrupt the proceduralist accumulation of precedent favoring freedom of commerce and speech over the protection of bodies from harm. ${ }^{1}$

\section{Commercial Sex, Human Trafficking, and Slavery ${ }^{2}$}

I begin with a brief description of the three cases under consideration here. The first, filed on September 16, 2010 in US District Court, Missouri, sought justice for M.A., a 13-year old child who was recruited at a fast food restaurant after she snuck out of her mother's home to attend a party. The child was missing for 270 days and raped repeatedly as a result of being sold online via Backpage.com. On August 15, 2011, the Court decided against M.A., dismissing the case on the basis that Backpage.com is protected under Section 230 of the CDA. No appeals were filed.

The second case involves a 15-year old who ran away from home and was recruited at a teen homeless shelter in Tacoma by an older woman to "go to the beach." Within hours, the child was being sold repeatedly on Backpage.com. She was missing for 180 days. This case, originally filed in 2013, is the only case brought by a child against Backpage.com to survive a motion to dismiss. In this potentially precedent overturning (and re-setting) case, the Washington Supreme Court decided that there was enough evidence against Backpage.com to support moving to discovery and litigation in a trial set for May 2017.

The final case against Backpage.com was brought by Boston law firm Ropes and Gray in 2014 on behalf of three minor children trafficked for sex in Massachusetts and Rhode Island via online advertisements on Backpage.com. Like the others, this suit sought to hold Backpage.com accountable for alleged criminal actions to facilitate the efforts of sex traffickers to sell children on its site. Backpage.com's Motion to Dismiss was granted by the federal district court judge in May, 2015, on the basis that Backpage.com was acting as a publisher of third party content and thus, was protected by Section 230 . The 1st Circuit Court of Appeals upheld that ruling in March of 2016, expanding the protective coverage of Section 230 to an unprecedented extent: that Section 230 would protect a publisher who was a co-conspirator in a federal crime-in this case, the crime of child sex trafficking. A last challenge was filed on behalf of the Jane Does in the US Supreme Court, which declined in January 2017 to hear the case.

Unfortunately, the outcomes on behalf of the Jane Does are not surprising. Cases brought on behalf of minor children trafficked online for commercial sex unfold within a turbulent social and political field dominated by a split between, on one hand, those who seek to decriminalize prostitution, defining it as labor and arguing that criminal stigma and consequences cause far graver violence to sex workers than the harm typically associated with the act of commercial sex itself, and, on the other, those who seek to end trafficking by employing various models of prevention and criminalization of transactional sex. Consensus among those in the latter camps has converged around what has come to be known as the Nordic Model, whereby the purchase of sex is criminalized but the sale is not, thereby shifting attention to the demand side of the transaction and correcting the previous legal travesty by which those who sold sex suffered criminal consequences while those who purchased it walked free. At the same time, international agencies such as the United Nations, the World Health Organization, and the International Labor Organization (ILO) have advocated for the rights of sex workers, and Amnesty International, arguably the world's largest human rights organization, formally adopted in 2015 a policy that calls for the end of decriminalization of all consensual sex work. The trouble with that policy, of course, is identifying "consensual" v. "nonconsensual" sexual transactions in a fundamentally coercive environment where

\footnotetext{
${ }^{1}$ The cases under discussion here are explored in depth in the documentary feature I Am Jane Doe, Dir. Mary Mazzio (2017), which chronicles the fight against Backpage.com waged by the minor survivors, their families, and others who support their struggle.

2 My discussion of the commercial sex trade relies on data from the International Labor Organization Global Estimate of Forced Labor (2012a), which estimates that of the 20.9 million people currently trapped in forced labor, 4.5 million are victims of forced sexual exploitation; of these, $98 \%$ are women or girls (see International Labor Organization, 2012b). Plaintiffs in each of the cases under consideration in this article are minor girls. Gendering sexually exploited people female in this work is not meant to discount the experiences of male or transgender persons engaged in the commercial sex trade and/or experiencing commercial sexual exploitation.
} 
freedom of choice, as commonly understood, is absent. This brings us to the issue of the relation between commercial sex, trafficking, and slavery.

Volumes have been written on issues of consent and agency, and on definitions of slavery, trafficking, and bondage in relation to the commercial sex trade, and it is beyond the scope of this work to parse those debates. The ILO defines forced labor (e.g., nonconsensual sex work) quite simply as a situation in which persons are made to work against their free will. The scholarly organization Historians Against Slavery, made up of leading scholars of slavery and abolition, adds "for the profit of others" to this definition (Historians Against Slavery, n.d.). ${ }^{3}$ The United Nations Protocol to Prevent, Suppress and Punish Trafficking in Persons Especially Women and Children, supplementing the United Nations Convention against Transnational Organized Crime-the Palermo Protocol-(United Nations General Assembly, 2000b) defines trafficking as:

[T] he recruitment, transportation, transfer, harbouring or receipt of persons, by means of the threat or use of force or other forms of coercion, of abduction, of fraud, of deception, of the abuse of power or of a position of vulnerability or of the giving or receiving of payments or benefits to achieve the consent of a person having control over another person, for the purpose of exploitation. Exploitation shall include, at a minimum, the exploitation of the prostitution of others or other forms of sexual exploitation, forced labour or services, slavery or practices similar to slavery, servitude or the removal of organs.

Significantly, according to this Protocol, the exploitation of a child need not be the result of coercion or any of the other means listed above; a child is defined as any person under 18 years of age. The cases under consideration here were all presented on behalf of minors; thus, according to international and domestic law, there is no disagreement about whether or not their exploitation meets the legal definition of trafficking. It does. As a legal matter, there is no consent.

Still, acknowledging the complexity of the debates and the difficulty of concretely identifying slavery and trafficking in the contemporary global context, I embrace Joel Quirk's (2011) theorization of "sufficient similarity" as a way of identifying forms of human bondage that resemble classical (transatlantic) slavery closely enough to demand redress, accepting that "the practices in question are not always identical, yet...still share sufficient features in common to be placed on the same footing" (p. 9). Considering the long and deeply contested history of activism and legislation against commercial sexual exploitation, I also find Quirk's identification of abolition as an "anti-slavery project" to be a useful framework, inasmuch as it provides room for nuance to consider different forms of bondage along with the range of strategies and uneven progress in disrupting them, all without reducing the histories of slavery and anti-slavery initiatives to a "linear or teleological process" (p. 19).

Significantly, as Quirk notes, from the first steps toward legal abolition of slavery in the mid-eighteenth century to the ongoing anti-trafficking activism of the $21^{\text {st }}$, "there was a significant pattern of delay, deflection, and dilution. These strategies may not amount to much in macro-historical terms, since slavery was eventually [legally] abolished, but their cumulative human cost was astronomical" (p. 19). My purpose here is to restore the account of such human cost to the narratives of the Jane Doe plaintiffs, who most certainly experienced treatment that bears "sufficient similarity" to slavery. Doing so requires illuminating plaintiffs' lived experiences and the claims for justice to which they give rise from within the shade of the normative world, or nomos, that has grown up around legal efforts to redress child sex trafficking today.

\section{Commercial Sex: From the Streets to the Internet}

The problem at issue in the St. Louis, Tacoma, and Boston cases is not whether the child plaintiffs were trafficked for commercial sex (a fact accepted by the court in each case), but rather whether Backpage.com, the internet service provider that hosted the ads initiating their violation, can be held at least partially responsible for that crime. In order to understand the relevant legal issues, let us first consider the shift of the commercial sex trade from "the streets" - the "stroll," massage parlor, brothel, etc. - to the internet, wherein the seller of sex acts is identified via an online host and details for the transaction, including meeting place, are arranged online and/or by telephone. This shift arose as the internet developed as a technology and means of connection, communication, and commerce in the late 1990s and early 2000s, and has also been associated with the widespread racialized gentrification and "law and order" policing that mark this period.

Sociologist Elizabeth Bernstein correlates the shift of commercial sex from street to internet with other socioeconomic trends, including the rise of the post-industrial service and tech industries and the deconstruction of traditional marriage and family ties. As Melissa Gira Grant (2014) notes in a description of Bernstein's research, "In an economy in which workers of all kinds are called on to produce an experience-not just a coffee, but a smile and a personal greeting; not just a vacation, but a spiritual retreat-sex work fits quite comfortably" (p. 95). This focus upon an "experience" accounts for a broad expansion in the menu of sexual services in the online market, from simple acts ("hand job," oral, intercourse) to performative role-play of everything from BDSM and fetish to "Girlfriend Experience (GFE)." This latter constitutes what Bernstein calls "bounded intimacy," available for sale in a world dominated by work and market forces

\footnotetext{
${ }^{3}$ Full disclosure: I sit on the board of this NGO.
} 
with little time and less interest in the demands of longterm emotional investments.

This trend toward transactional socio-sexual relations extends far beyond the world of commercial sex, as Bernstein (2007) notes:

Sociologists of culture have...pointed to a general trend of 'disenchantment' or 'cultural cooling' whereby intimate exchanges have increasingly come to resemble other forms of utilitarian exchanges. Whether in the guise of...efficiently managed 'quality time' with one's own children, or via an emerging ideology of romantic love that 'endorses flexibility and eschews permanence,' public-sphere market logics have become intricately intertwined with privatesphere emotional needs. (p. 5)

Interestingly, these trends mirror the broader neoliberal embrace of freedom of markets and commerce at the expense of bodies and humans, a worldview that "sees competition as the defining characteristic of human relations. It redefines citizens as consumers, whose democratic choices are best exercised by buying and selling, a process that rewards merit and punishes inefficiency. It maintains that the 'market' delivers benefits that could never be achieved by planning" (Monbiot, 2016). Interestingly, this description of dominant neoliberal ideology resonates with Bernstein's observation, based in fieldwork with members of COYOTE (Call Off Your Old Tired Ethics), the nation's first sex worker rights organization, that "the ethical and social world they inhabited was a fair approximation of 'the universal market in bodies and services' that feminist political theorist Carole Pateman predicted would arise if the logic of contract were allowed completely free reign" (Bernstein, 2007, p. 106; see also Pateman, 1988).

The logic of contract, the emphasis upon free market competition, the definition of citizens as consumers, the allegiance to commerce over citizens, as well as cultural assumptions about consensual sex work-all are at play in the many legal decisions that have allowed Backpage.com to continue operations despite overwhelming evidence unearthed by the US Senate of Backpage.com's complicity with commercial sexual exploitation writ large, and more specifically and egregiously, with the trafficking of minor children for sex. Substitute "property" for "commerce" in the sentence above and the through-line of such logics that support rights of property/commerce over personhood/protection is made visible, thereby situating the Jane Doe cases in the long history of US slavery and its enabling legal apparatus. Indeed, the cases share many similarities with those that Cover analyzed in Justice Accused: Antislavery and the Judicial Process (1975), his seminal study of judicial conduct and decisions about slavery in the US, particularly the problem of judges caught in the "moralformal dilemma," or in the gap between what is morally right (liberty for all persons) and what is legally, proce- durally, and formally correct (state laws governing ownership or manumission, for instance, or federal laws such as the Fugitive Slave Act). In such cases, Cover concluded, judges faced with a moral dilemma consistently revert to "the highest justifications for formalism, the most mechanical understanding of precedent, and the steadfast excision of self and appeal to separation of powers" $(1975$, p. 258). As we shall see, precisely the same judicial maneuvers manifest in the Jane Doe cases.

\section{The Communications Decency Act (CDA) Section 230}

At the heart of Backpage.com's power to thwart legal responsibility for its part in the trafficking of minors for commercial sex is Section 230 of the CDA. Introduced by Senator James Exon of Nebraska, its purpose was to address concerns about the ease of access to pornography afforded by the internet, particularly for children, at a time when the internet was still very new. Congress was clear that its intent with the legislation was to "target content providers, not access providers or users;" however, Congress also made clear that "owners of telecommunication facilities are liable where they knowingly permit their facilities to be used in a manner that violates the CDA."

The most controversial aspect of the CDA, Section 230, was not found in the original Act, but rather was added by the House of Representatives as "The Internet Freedom and Family Empowerment Act." This law, which states that "No provider or user of an interactive computer service shall be treated as the publisher or speaker of any information provided by another information content provider," was prompted by a lawsuit filed in 1995 by Stratton Oakmont (a firm founded by Jordan Belfort and made famous by the Leonardo DiCaprio film, "Wolf of Wall Street"). Stratton Oakmont had filed suit against Prodigy (one of the earlier internet message boards) because someone had posted a comment asserting that Stratton Oakmont had been criminally manipulating stocks. Belfort's firm argued that because Prodigy filtered content but missed this post, it should be held responsible for third party content on its site. The court agreed, and Prodigy was held liable for defamation. Legislators, in turn, found this to be an alarming development, worrying about the "chilling effect" on the newly emergent internet economy should internet service providers be flooded with such lawsuits every time someone became upset by a posting or comment.

The irony is that had Prodigy not initiated any attempts to monitor and filter content-in other words, if it had done nothing to protect against indecency or defamation-it would not have been held responsible, and would have suffered no penalties. But because it had initiated such efforts and failed to catch a "defaming" post, it was held liable by the court. This, of course, was seen as a major disincentive for internet service providers (ISPs, such as AOL, Google...and Backpage.com) to take any steps toward monitoring the con- 
tent posted by third party users on their sites. In response, Section 230 legislatively overruled the Stratton decision by protecting from liability those providers who had made "good faith efforts" to monitor the content posted on their sites. Of course, the question of what constitutes "good faith" efforts by ISPs to filter indecent or defaming content remains undecided, with courts erring on the side of publishers in nearly every decision in which CDA Section 230 is evoked as a defense, even when those publishers have arguably not acted in good faith or have collaborated with users to create the content of their posts, and even when those posts constitute criminal activity-such as sex trafficking-under US law.

For the purposes of the cases examined below, the operative issues regarding Section 230 are:

1) whether Backpage.com can be treated as more than just the publisher of the ads in question, but rather as a participant in creating them. If it can be shown that Backpage.com developed "in whole or in part" the content of the ads that caused harm, then Backpage.com could be held liable because it would no longer be a passive publisher;

2) whether Backpage.com's stated efforts to identify and eliminate "escort" advertisements that feature minors constitute "good faith" efforts as required in Section 230(c)(2)(A) or, as a Congressional report on the matter asserts (in support of the many claims put forth by plaintiffs in state courts around the country), Backpage.com's "efforts" have more to do with inhibiting law enforcement attempts to identify such ads and helping pimps to post them without detection; and

3) whether civil private right of claims of criminal action can be brought under Section 230 (e)(1), which asserts that that "Nothing in this section shall be construed to impair the enforcement of section 223 or 231 of this title, chapter 71 (relating to obscenity) or 110 (relating to sexual exploitation of children) of title 18 , or any other Federal criminal statute."

In many ways, the struggle between Section 230 and the plaintiffs who have been harmed by the internet service providers it protects rests upon two points: precedent and jurisdiction (or separation of powers), both of which I address below through theories of legal interpretation. In each of the court decisions under examination here, as well as in many others, the court expresses dismay at not being able to offer remedy to plaintiffs, but, referring to the many precedents of cases dismissed on the basis of Section 230 protection, argues that the matter is for Congress to correct legislatively, rather than for courts to re-interpret what they see as the plain language of Section 230 to err on the side of protection for ISPs. As Judge Selya of the $1^{\text {st }}$ Circuit Court of Appeals put it in a phrase much-quoted by Backpage.com in its opposition briefs, "There has been near-universal agreement that Section
230 should not be applied grudgingly" (Jane Doe v. Backpage.com, 2016, p. 10). Nearly every opinion repeats the phrase that originated with Section 230, that allowing ISPs to be held liable for third-party content posted by their users would have a "chilling effect" on the opportunities for freedom of speech and commerce provided by the internet. It is worth noting that in the bulk of the 300 cases adjudicating Section 230, the majority involve defamation, and not allegations of criminal conduct. In response, plaintiffs and their amici argue passionately that in passing the CDA (major "decency" provisions of which were struck down as unconstitutional in the late 1990s, leaving only Section 230 as a basis for positive law in cases involving ISP liability), Congress did not mean to create a protected space-much less a broad immunity (a word used in several judicial opinions, but a word which does not appear in the statute itself) - for criminal enterprise on the internet that could not possibly be permitted in "brick and mortar" spaces. As Erik Bauer, lead attorney on J.S. v. Backpage.com in Tacoma, protests:

Prosecutors will go after a kid on the streets, an 18year old kid selling 12-year olds, but they won't go after Backpage...This is not about freedom of speech, this is not about freedom of sexuality, it's about the freedom of a kid to get raped by someone who has paid a pimp for the pleasure. It's about a company that has enabled that to happen on a massive scale, a company that has taken advantage of this miracle of marketing called the internet to blow human sex trafficking right through the roof. No one thinks that this is what Congress intended when they passed Section 230. (Bauer, 2016, interview with author)

The question remains whether the courts will continue to dodge the issue by referring it back to Congress, and whether, then, Congress will act legislatively to block the unintended escape route currently entrenched within the law.

\section{The Cases and the Legal Strategies}

Studying the cases brought against Backpage.com for their strategies and the grounds upon which plaintiffs' claims are brought is an exercise in the complexity of legal theory and method, and of the potential for violence inherent within judicial interpretation and the application of precedent. For our purposes, it is important to clarify the legal grounds upon which each team advanced its case, and the response of the courts to those claims in relation to the seemingly insurmountable barrier of Section 230 protection.

\subsection{St. Louis: M.A. v. Village Voice Media Holdings, LLC., and Backpage.com, LLC.}

In 2009, 13-year old M.A. ran away from home and was trafficked for commercial sex by Latasha Jewell McFar- 
land, who served time in prison on charges of sex trafficking and illegal interstate commerce as a result. As the ads used by McFarland to traffic M.A. were posted on Backpage.com, M.A. attempted to prove that Backpage.com's posting rules and limitations "aid in the sight veiling of illegal sex services ads to create the veil of legality" (M.A. v. Village Voice Media Holdings and Backpage.com, 2011, p. 187) and that therefore Backpage.com must be characterized as an "Information Content Provider," rather than simply a publisher of third-party content. As a content provider, Backpage.com would not be protected by Section 230 from processes of discovery and litigation related to criminal or civil charges. In addition to alleging criminal charges of aiding and abetting her traffickers, M.A. also argued that Backpage.com and its parent company, Village Voice Media Holdings, had violated her rights under the Optional Protocol to the Convention on the Rights of the Child on the Sale of Children, Child Prostitution, and Child Pornography (United Nations General Assembly, 2000a).

The Eastern District of Missouri Court in M.A. v. Village Voice Media Holdings and Backpage.com decided against M.A. on the basis of each of her claims, asserting that "The actual injury suffered by M.A. is, as she describes it, her victimization by McFarland," and that " $[\mathrm{H}]$ owever horrific the consequences to M.A. of McFarland's posted ads were, the ads were created by McFarland." Citing multiple Section 230 precedents, the court held that neither notice of nor profit from the unlawful nature of information provided by a third party renders an ISP liable for that information: "Section 230 immunity applies even after notice of the potentially unlawful nature of the third-party content" (Lycos, Inc., 478 F.3d at 420, quoted in M.A. v. Village Voice Media Holdings and Backpage.com, 2011, p. 199). The aiding and abetting charges were dismissed based upon precedent that requires intention to commit the particular crime in question; here, the opinion states that "[M.A.'s] allegations of Backpage.com aiding and abetting McFarland do not describe the specific intent required for aiding and abetting....Rather, those allegations describe only a violation of Section 2255 by 'the creation and maintenance of [a] highly effective internet tool" (M.A. v. Village Voice Media Holdings and Backpage.com, 2011, pp. 206-207). The court also denies M.A.'s right to civil remedy for criminal actions under Section 2255 (which allows for civil remedy for personal injuries to minors), asserting that Section 230(e)(1) only allowed for prosecution of ISPs on federal criminal, not civil grounds (a problem of jurisdiction).

Finally, the court denied M.A.'s contention that the Optional Protocol to the Convention on the Rights of the Child superceded Section 230's protective provision on the grounds that while the Optional Protocol constitutes an international law commitment, it does not by itself function as binding federal law (M.A. v. Village Voice Media Holdings and Backpage.com, 2011, p. 212). Instead, when the Senate ratified the Optional Protocol, it did so as a non-self-executing treaty, meaning that it would not create privately enforceable rights because its provisions are already covered under existing domestic law. And under that law, according to the court in this case, M.A.'s remedies begin and end with her suit against her trafficker, Natasha Jewell McFarland, because the host of ads posted by her trafficker, Backpage.com, was protected under Section 230 of the CDA.

Several times throughout the opinion, the court expressed "sympathy" for the "horrific" circumstances of M.A.'s "victimization," but in each case, it wrung its hands, making clear that the court was constrained (1) by the jurisdiction of Section 230 ("Thus, regardless of M.A.'s characterization of the policy choice of denying Section 230 immunity in such circumstances as alleged as "clear," it nonetheless is a matter Congress has spoken on and is for Congress, not this Court, to revisit"); (2) by the procedural distinction of a civil remedy, even one conferred as a private right of claim under a federal criminal statute, versus federal criminal liability as read through Section 230, finding in favor of the latter; and (3) by the failure of Congress to create privately enforceable rights under international law. The court concludes:

Plaintiff artfully and eloquently attempts to phrase her allegations to avoid the reach of Section 230. Those allegations, however, do not distinguish the complained-of actions of Backpage.com from any other website that posted content that led to an innocent person's injury. Congress has declared such websites to be immune from suits arising from such injuries. It is for Congress to change the policy that gave rise to such immunity (2010, p. 215).

This theme of "artful" framing of "sententious" claims arises again in the Boston case, below, and can be read as one of many rhetorical strategies evidenced in court opinions that bracket or disparage plaintiffs' accounts of suffering so as to dismiss them in favor of precedent and jurisdiction arising from Section 230.

Such interpretation on the part of judges reveal a nomos that devalues the rights of children as a special category while also operating according to dominant gender norms that, as children's rights advocate Barbara Bennett Woodhouse (2008) asserts, "generate cultural stereotypes, which in turn generate laws based on these disabling stereotypes" (loc. 1073). Such gendered stereotypes are particularly damaging in the case of children trafficked for commercial sex, who are often seen as "just another 'teen prostitute'...nameless, faceless, ignored, already damaged..." (Lloyd, 2011, loc. 699). In just one example of the manifestation of gendered cultural attitudes in the Jane Doe cases, Judge Richard Posner, writing for the $7^{\text {th }}$ Circuit in Dart v. Backpage.com, LLC, 2016, acknowledged that a majority of ads on Backpage.com's adult section are for sex, but went on to assert that "a majority is not all, and not all advertisements for sex are advertisements for illegal sex." In seeking to protect such "legal" commercial sexual transactions, Judge Posner re- 
marked in open court, "What about also old people, old men who like to be seen with a young woman, right. That is an aspect of escort service, it's not all sex." This judicial comment reveals the normalization of cultural attitudes toward men's right to access women's bodies, regardless of age or of the potential for harm. As Rachel Lloyd, prostitution survivor and founder of Girls Educational and Mentoring Service-a NYC agency that provides services for girls and women who have survived commercial sexual exploitation-is at pains to make clear, public sympathy is retained for the few cases of abducted "Amber Alert" children, those who fit a gendered and raced image of purity and innocence, as opposed to the majority of commercially sexually exploited children who are homeless or runaways:

These girls and young women have a tougher time in the court of public opinion and in the real courts of the criminal and juvenile justice systems. It is presumed that somewhere along the line they 'chose' this life, and this damns them to be seen as willing participants in their own abuse (2011, loc. 1103)

As we will see, such deeply entrenched cultural attitudes toward gender and sex find their way into the opinions issued by judges in each of the Jane Doe cases such that the testimony of these child plaintiffs to severe harm is read-and dismissed-as merely "artful" or "eloquent" distractions from the weightier truth of the law and its precedents.

\subsection{Washington: J.S., S.L., and L.C. v. Village Voice Media Holdings, L.L.C., and Backpage.com, L.L.C.}

The circumstances in J.S. v. Village Voice Media Holdings and Backpage.com are similar to the St. Louis and Boston cases, in that plaintiffs (collectively "J.S.") were each between the ages of 13 and 15 years old when trafficked for commercial sex by third parties on Backpage.com. The suit asserts state law claims of negligence, outrage, sexual exploitation of children, ratification/vicarious liability, unjust enrichment, invasion of privacy, sexual assault and battery, and civil conspiracy as well as a private right of claim conferred under federal criminal statutes which criminalize "participation" in the sex trafficking of children. Unsurprisingly, Backpage.com moved to dismiss the claims on the grounds that federal law (Section 230) preempts both state law and federal private right of claims; however, the case, which was appealed to the Washington State Supreme Court, was decided, surprisingly, in favor of the Jane Doe plaintiffs. The court concluded that the plaintiffs had alleged sufficient facts to support the conclusion that Backpage.com was not simply a passive publisher, but was actively involved in creating content. The court stated: “Backpage.com's advertising posting rules were not simply neutral policies prohibiting or limiting certain content but were instead 'specifically designed...so that pimps can continue to use
Backpage.com to traffic in sex"' (J.S. v. Village Voice Media Holdings and Backpage.com, 2015, p. 8). These rules and policies include age verification with prompting from the website (if a user enters an age under 18, they receive an "oops" message that users must be 18 years of age or older, at which point they are prompted to re-enter an age, without verification); stripping of meta-data from posted images so that they cannot be traced; encouragement of the use of pre-paid credit cards in order to assure anonymity of users, who are not required to provide other identifying information, such as a telephone number; and finally, as the United States Senate Permanent Subcommittee on Investigations later reported:

Backpage.com has knowingly concealed evidence of criminality by systematically editing its 'adult' ads....The terms that Backpage.com has automatically deleted from ads before publication include "Lolita," "teenage," "rape," "young," "amber alert," "little girl," "teen," "fresh," "innocent," and "school girl." (United States Senate, 2017, p. 2)

J.S. v. Village Voice Media Holdings and Backpage.com begs the question of why the Supreme Court in the State of Washington concluded that "[f]act-finding on this issue is warranted" when so many other courts have succumbed to Section 230 pressure (read: precedent), allowing that even if it was clear that "horrific" acts had been committed from within that shield, it was for Congress and not the courts to remedy. One clue is to be found in the concurring opinion of Justice Charles Wiggins, who writes separately "to emphasize that this holding implies that the plaintiffs' claims do not treat Backpage.com as the publisher or speaker of another's information under the CDA Section 230" (J.S. v. Backpage.com, Wiggins, J., Concurring, 2015, p. 1). Wiggins continues:

Backpage.com argues that plaintiffs' inducement [to sex trafficking] theory clearly treats them as publishers and that holding it liable would punish the company for publishing third party content. To the contrary, plaintiffs have alleged a totally different theory-that Backpage.com guided pimps to craft invitations to prostitution that appear neutral and legal so that the pimps could advertise prostitution and share their ill-gotten gains with Backpage.com. Plaintiffs are not claiming that backpage.com itself is acting as their pimp but that Backpage.com is promoting prostitution, which is a crime in Washington...and should support a cause of action (J.S. v. Backpage.com, Wiggins, J., Concurring, 2015, p. 10).

Here we see the power of straightforward federal and state statutes to address the immunity provision of Section 230 head on. As Attorney Erik Bauer shares:

Section 230 protects internet sites from getting sued because of third party content, and it's been tightly in- 
terpreted. The way the statute reads, the keywords to consider are whether an online publisher is "responsible in whole or in part for the creation or development of illegal content." The statute does not say you have to author the bad content; it says you have to be responsible in part for the creation or development of illegal content. If they wanted to say authorship, they would have said authorship. They didn't use that term. (Bauer, 2016, interview with author)

In other words, while Backpage.com and the courts that have sided with it in Section 230 cases contend that they did not author the content of the ads, and therefore are protected by Section 230 against liability for harm arising from them, the statutory language "responsible in part" provides enough room for the courts to find against the shield of Section 230.

The court in this case agrees, and also takes issue with the term "immunity" as repeated in many decisions that treat ISP's as publishers, noting that the word does not appear anywhere in the statute, and that:

Subsection $230(c)(1)$ is neither an immunity nor a defense; it is a prohibition against considering the provider as a publisher or speaker of content provided by another. The main purpose of subsection 230 (c) is not to insulate providers from civil liability for objectionable content on their websites, but to protect providers from civil liability for limiting access to objectionable content. (J.S. v. Backpage.com, 2015, Wiggins, J., Concurring, p. 5; emphasis mine)

Finally, the court does not accept Backpage.com's avowal that their efforts to prevent child sex trafficking constitute "good faith" efforts, and decides to allow discovery to proceed in order to...discover more. The failure of other courts in the country to allow for such discovery has frustrated plaintiffs and their teams, along with the Senate Permanent Subcommittee on Investigations, all of whom desire the opportunities afforded by the discovery process in order to more fully understand the nature of the harms they seek to address.

In considering the Tacoma decision as an outlier, a great deal turns on the court's navigation of Section 230, which runs against the tide of majority precedent, as well as its belief that "It is important to ascertain whether in fact Backpage.com designed its posting rules to induce sex trafficking to determine whether Backpage.com is subject to suit under the CDA" (J.S. v. Village Voice Media Holdings and Backpage.com, 2015, p. 8). Again, keep in mind that each of these cases, having been dismissed at the federal district court or federal magistrate level, advanced to the appeals phase simply asking to proceed to discovery and trial, to be permitted to in- vestigate claims of participation in what judges in these cases unanimously acknowledge to be serious crimes with grave injuries. Compare the majority decision to allow the question to be explored in discovery and trial with the dissenting opinion, which concludes:

This case does not ask us to decide whether pimps should be able to traffick [sic] our children without consequence. The answer to that question is certainly no. And this case does not ask us to decide whether third party accomplices or co-conspirators should be able to escape criminal prosecution for human trafficking and child rape. The answer to that is also a resounding no. Instead, the question before us is whether the CDA, a federal statute, shields this defendant from this state law claim. Using settled principles of statutory interpretation, the CDA compels me to conclude that the answer to that question is [yes]. ${ }^{4}$ (J.S. v. Village Voice Media Holdings and Backpage.com, 2015, Gordon McCloud, J., Dissent, p. 40)

If one thinks in terms of what Robert Cover calls "the reality of common meaning," then the first two "no's" advanced by McCloud in her dissent cannot co-exist with the "yes" response to the third question; instead, her rhetoric reveals the violent dissonance of the law whereby, as Colin Dayan avers, "To think legally is to be capable of detaching ways of thinking from what is being thought about" (Dayan, 2011, p. 12). Here, what is being thought about is the rape of minor girls for the profit of others, but the judge is "compelled" by the CDA and its accompanying "settled principles of statutory interpretation" (precedent) to position herself in the absurd breach that separates that harm from its redress.

\subsection{Jane Doe No. 1 et al. v. Backpage.com, L.L.C. et al.}

The final case under examination is Jane Doe No. 1 et al. v. Backpage.com, L.L.C., brought in Boston in May 2015 on behalf of three minor girls trafficked for commercial sex using ads posted on Backpage.com. This case, brought by Boston law firm Ropes \& Gray, alleges violations of the federal William Wilberforce Trafficking Victims Protection Reauthorization Act, the Massachusetts Anti-Human Trafficking and Victim Protection Act, as well as copyright infringement, unfair business practices, and violation of privacy statutes. Here too, both the initial complaint and the appeal in Boston's First Circuit Court of Appeals failed on the basis of CDA protection, as did a plea to the United States Supreme Court to take the case. I analyze this case and the rhetoric of the written opinion in greater detail below as the clearest example of a court bracketing the harm done to human bodies, in this

\footnotetext{
${ }^{4}$ The original text of the opinion reads "Using settled principles of statutory interpretation, the CDA compels me to conclude that the answer to that question is also no. J.S. fails to allege facts sufficient to provide that Backpage was a content provider as opposed to a service provider. Thus, subsection 230 immunizes Backpage from liability for JS's claims. And Subsection 230 trumps conflicting state law claims." It appears from the sense of the text that the opinion mistakenly asserted that the answer to the third question was also "no," but in fact the Justice means that the answer is "yes."
} 
case via sex trafficking, failing to address the gaping hole in Section 230 that allows for criminal activity to take place because of a reliance upon what Colin Dayan calls a "hoard" of precedent and what Robert Cover calls "deference to political branches" (Dayan, 2011, p. 9; Cover, 1986, p. 58).

\section{The Violence of the Law}

It was perhaps his early immersion in the history of United States slavery laws that gave rise to Robert Cover's later seminal work on the distance between the law and the experiences of those who must live under it-for surely there rarely has been such an egregious detachment of legal interpretation from its lived implications than that exemplified in the various laws and codes governing enslaved people and property in the antebellum US. Cover first explored the question of unjust law in Justice Accused: Antislavery and the Judicial Process (1975), going on to write two landmark essays on the subject of the "dissonance of the lawfulness of the intolerable" in the 1980s (Cover, 1986, p. 39). ${ }^{5}$ These essays have guided scholarly thinking in the intervening years about how legal interpretation often hinders, rather than supports, the distribution of justice. While Cover's essay addresses the harm done to criminal defendants, not plaintiffs, the overarching analysis of judicial behavior is relevant to our discussion here.

For Cover (1983), the problem is that jurists often fail to understand, on the one hand, the relation between the law and its interpretation, and on the other, the normative world, or nomos, ${ }^{6}$ within which the law operates: "Once understood in the context of the narratives that give it meaning, law becomes not merely a system of rules to be observed, but a world in which we live" (pp. 4-5). Cover (1983) recognized the force of the nomos as being every bit as influential as "the physical universe of mass, energy, and momentum" (p. 5), and more, identified this force as a violent one (1986): "Between the idea and the reality of common meaning falls the shadow of the violence of the law itself" ( $p$. 1629). Cover understood that the accumulation of law over time through precedent and jurisdiction could be world creating or world destroying, and that it was largely up to judges, as individuals and representatives of the law, what kind of worlds would be engendered, which would survive and which would be crushed. As Cover put it, "Judges are people of violence. Because of the violence they command, judges characteristically do not create law, but kill it....Confronting the luxuriant growth of a hundred legal traditions, they assert that this one is law and destroy or try to destroy the rest" (1983, p. 53).

We witness this confrontation among competing legal claims and traditions in the Backpage.com cases, an- alyzing the judicial response through the trail left by the written opinions. In St. Louis, Tacoma, Boston, and the many other cases against ISPs for their role in harm done by postings on their internet sites, plaintiffs challenged one law, Section 230, with others: criminal and civil statutes at federal and state levels, as well as international protocols and laws. In each case, the judges favored the nomos of one law-overwhelmingly, Section 230-over the others. Each court took it upon itself to determine which law should prevail in the event of a conflict of laws-and in every case except for Washington State, these judges found in favor of Section 230. The prevailing nomos accompanying the chosen law is the neoliberal vision of unfettered markets and revenue generation, while the nomos lost as a result of the judgments prioritizes human rights and protections from harm, particularly for children who are defined a priori within the law as vulnerable. In other words, even when confronted with two federally enacted statutes, one much later than the other (typically, later statutes take precedence over earlier ones in the case of a conflict), the courts have continued to generate positive legal outcomes-e.g., lawaround freedom of speech and markets (Section 230), and negative legal outcomes around statutes meant to protect bodies from harm (the Trafficking Victims Protection Act, the Optional Protocol to the Convention on the Rights of the Child, criminal trafficking and child sexual exploitation statutes).

Let us examine how this "jurisgenerative" principle works in practice, using the opinions set forth in the three cases above. For both Cover and Dayan, "It is through law that persons, variously figured, gain or lose definition, become victims of prejudice or inheritors of privilege. And once outside the valuable discriminations of personhood, their claims become inconsequential" (Dayan, 2011, p. i). Here we can see the persons of Ferrer, Lacey, and Larkin, as well as their proprietary manifestation of corporate personhood, Backpage.com, gain definition, standing, and the privilege to continue generating profit each time Section 230 is used as a shield against what a jurist in the J.S. v. Village Voice Media Holdings and Backpage.com trial court proceeding concedes is too obvious to ignore: "And, frankly, my note to myself in the sideline was Backpage.com doesn't know this is for prostitution and isn't assisting with the development? And despite the case law, I answer that question on the side the plaintiffs and I'm denying [Backpage.com's motion to dismiss]" (quoted in J.S. v. Village Voice Media Holdings and Backpage.com, 2015, Gordon McCloud, J., Dissent, p. 5). In this case, the judge bridges the gap between "the reality of common meaning" and the exercise of the law, erring on the side of the nomos experienced by vulnerable people subjected to harm rather than that of ISP's generating revenues and profits. In order to do so, how-

\footnotetext{
${ }^{5}$ These two essays are The Supreme Court, 1982 Term-Foreword: Nomos and Narrative (1983) and Violence and the Word (1986).

${ }^{6}$ In current usage, nomos refers to "the law; principles defining human conduct originating especially from culture and custom." The term originates from the classical Greek for usage, custom, law, melody, composition (Oxford English Dictionary online, n.d.). While nomos evokes and constitutes the law, its meaning extends into the realm of the shared, ever-evolving, and often intractable cultural, historical, and ethical narratives that constitute the "normative universes" in which we live.
} 
ever, she must transcend or override the power of precedent and jurisdiction, both.

In her analysis of the violence of the law, Dayan describes "sinkholes of law where precedents gather, festering as they feed on juridical words, past and present" (p. 9). For Cover (1983), too, precedents can generate:

...an entire nomos - an integrated world of obligation and reality from which the rest of the world is perceived. At that point of radical transformation of perspective, the boundary rule...becomes more than a rule: it becomes constitutive of a world. We witness normative mitosis. A world turned inside out; a wall begins to form and its shape differs depending on which side of the wall our narratives place us." (p. 31)

While the judges in the Tacoma case scale narrowly down the side of the wall accommodating allegiance to victims of profound harm, those in the Boston case land on the opposite side; indeed, as John Montgomery, lead attorney for the Jane Doe plaintiffs in Boston, wrote in his Reply Brief petitioning for appeal by the US Supreme Court, "Had petitioners' exact allegations been asserted in a district court in the Ninth Circuit, or in Washington State court, their claims would not have been dismissed" (Jane Doe v. Backpage.com, Reply Brief, p. 5). This is because the judges in the Ninth Circuit departed from the "hundreds of reported decisions [that] have interpreted Section 230...[finding] that the website is entitled to immunity from liability" (Jane Doe v. Backpage.com, Opp. Brief, 2016, pp. 4-5). And indeed, negative responses to the J.S. decision ground their claims in the argument that J.S. "deviates from precedent" and "subverts the policy rationales behind Section 230," thereby "mark[ing] the opening of the metaphorical litigation floodgates [and] impeding policy goals such as technological innovation, user control, and choice in the free markets" (Lee, 2016, p. 12). Characterizing sex trafficking, especially of minors, as a "serious and sensitive public policy issue in Washington" rather than a serious and gravely harmful criminal act and human rights violation, the comment finds the Ninth Circuit court's discretion in allowing the case to proceed to trial "unwelcome in a judicial system that emphasizes the predictability of legal outcomes [and] highly detrimental to ISP's, which seek clear precedents for their business decisions" (Lee, 2016, p. 16, emphasis added). Witness what Cover called "normative mitosis": the creation of a world in which the ability of corporations to plan business decisions based upon the extent to which they can count on precedent to protect them from criminal liability takes precedence (entendre intended) over the right of children to be protected from trafficking, sexual exploitation, and rape.

Further, the rhetoric of Judge Bruce M. Selya in the First Circuit court of Appeals (Boston) contributes to the creation of this nomos inasmuch as his opinion adopts a style of rhetorical gamesmanship in tackling plaintiffs' claims one by one, bracketing the gendered harm done to the plaintiffs in the process of interpreting and upholding Section 230 precedent against them. As it happens, Judge Selya is known for his complex, "quirky," and erudite writing style; still, as one commentator pointed out, his flourishes can "demean litigants and the legal process" (Garner, quoted in Margolick, 1992). ${ }^{7}$ They certainly do in the Jane Doe case, in precisely the manner that worries legal scholars like Cover and Dayan.

Selya begins by acknowledging the difficulty of the case because of the bodily harm suffered by plaintiffs: "This is a hard case-hard not in the sense that the legal issues defy resolution, but hard in the sense that the law requires that we, like the court below, deny relief to plaintiffs whose circumstances evoke outrage" (Jane Doe No. 1 et al. v. Backpage.com, 2016, p. 3). Granted, Selya does not acknowledge that he or the other two justices hearing the case themselves experience outrage at the plaintiffs' circumstances, only that the circumstances (which he declines to name or define) evoke outrage in the abstract; to be sure, there is precious little by way of attention to such outrage in the opinion that follows. Indeed, Selya later asserts that:

[T]he appellants contend that [Backpage.com's] course of conduct amounts to participation in sex trafficking and, thus, can ground liability without treating Backpage.com as the publisher or speaker of any of the underlying content. This contention comprises more cry than wool. (Jane Doe v. Backpage.com, 2016, p. 14)

"More cry than wool" is an antiquated proverb that originated with the cries made by sheep while being shorn, the assumption being that there is no real pain in those cries, and the proverb coming to mean a "dramatic assertion backed by little evidence" (Simpson \& Speake, 2008). Selya's use of a figure of speech that makes its meaning by dismissing the substance of an expression of pain emanating from another being is more in keeping with the treatment by the court of the suffering experienced by plaintiffs than his earlier abstract characterization of their claims as "circumstances that evoke outrage." It demonstrates the overall glossing over of plaintiffs' suffering evidenced throughout the opinion.

Selya concludes his brief introduction to the case with the simple sentence, "The tale follows," thereby highlighting what Dayan calls the "achingly disparate significant experience" of the judge (perpetrator) and plaintiff (victim) of the "organized violence" that is law:

For the perpetrator, the pain and fear are remote, unreal, and largely unshared. They are, therefore, almost never made a part of the interpretive artifact, such as the judicial opinion....[F]or those who impose the violence the justification is important, real and carefully cultivated. Conversely, for the victim, the justification

\footnotetext{
${ }^{7}$ Thanks to David Nersessian for bringing this matter of Selya's unique writing style to my attention.
} 
for the violence recedes in reality and significance in proportion to the overwhelming reality of the pain and fear that is suffered." (2011, loc. 1629)

For Selya, "Striking the balance in a way that we believe is consistent with both congressional intent and the teachings of precedent" is an important, real, and carefully cultivated justification for denying relief for the pain and fear of plaintiffs who, as a result of this opinion, will not be entitled to relief, redress, or justice (Jane Doe v. Backpage.com, p. 3). To preface one's rationale for an opinion that destroys a person's ability to pursue justice by introducing it as a "tale" ("a story imaginatively told," according to the Oxford English Dictionary online, n.d.) is to trivialize the narrative of suffering experienced by but not limited to the three plaintiffs in the case. Selya's tale is a remote walk through judicial precedent and legislative intent, while the claimants' tale is a horror story: the dehumanization, exploitation, and rape of children to line another's pockets. But Selya's prevails, thereby providing a cautionary "tale" to other victims who might seek protection in the courts: don't bother.

Despite these stakes, Selya proceeds through the opinion as if it is simply a tale, or a game, at stake, embracing without ambivalence Section 230 precedent throughout, as when he triumphantly claims, "Precedent clinches the matter" (Jane Doe v. Backpage.com, p. 15). He further characterizes the complaint as reliant upon "sententious rhetoric rather than well-pleaded facts" (p. 18) or upon charges of "Machiavellian manipulation...as surrogates for well-pleaded facts" (p. 19); designates plaintiff's claims about the status of Backpage.com as participant in the development of its online posting as "a pair of end runs" around Section 230 (p. 19); calls plaintiff's claim that Backpage.com profited from unauthorized use of the girls' photos as a "fusillade wide of the mark" (pp. 29-30); and describes plaintiff's final contention that their right to privacy was violated when Backpage.com posted their photos as "a last ditch effort to bell the cat" (p. 35).

In addition to likening the plaintiff's claims to (failed) tactical moves in sporting events and war games, Selya diminishes the assertions of harm embedded therein in gendered terms as hyperbolic, hysterical, or pompously moralizing, in contrast with the rationality of "wellpleaded facts." In the rare moments when he appears to acknowledge such suffering as real or true, he then dismisses it on the basis of both precedent and jurisdiction, as in his conclusion:

"As a final matter, we add a coda. The appellants' core argument is that Backpage.com has tailored its website to make sex trafficking easier. Aided by the amici, the appellants have made a persuasive case for that proposition. But Congress did not sound an uncertain trumpet when it enacted the CDA, and it chose to grant broad protections to internet publishers....If the evils that the appellants have identified are deemed to outweigh the First Amendment values that drive the CDA, the remedy is through legislation, not through litigation. We need go no further" (Jane Doe v. Backpage.com, 2015, p. 37, emphasis added).

\section{Conclusion}

We need go no further. It is perhaps this tone of certitude that clinches (to borrow from Selya) the interpretive violence of this decision. For indeed we must go further, and as current events would have it, will go further. The nomos of certitude around Section 230 has been unsettled in legislative, criminal, and judicial contexts. The Senate Permanent Subcommittee on Investigations held Carl Ferrer in civil contempt of Congress for refusing to reply to its subpoena for information on Backpage.com business practices or even to show up to a hearing on the matter in November 2015. In January, 2017, Ferrer, Lacey, and Larkin were forced to appear before the Subcommittee, at which time they each invoked their Fifth Amendment rights not to testify, a move that "validat[es] the Senate's report on their illegal activities," according to Subcommittee Chair Senator Rob Portman, who adds that Backpage.com has "put profits ahead of vulnerable women and children"-as, indeed, the judicial interpretation of Section 230 and the accumulation of precedent has allowed them to do (quoted in Daly, 2017). And while the October 2016 pimping charges against Ferrer, Lacey, and Larkin were dropped (by a court that accepted Section 230 as sufficient prophylaxis against criminal liability), the State of California has brought new charges that led to another indictment for Ferrer, Lacey, and Larkin. Finally, the Tacoma case against Backpage.com in the Ninth Circuit on behalf of J.S. will go forward in May, 2017. Should it succeed, an important new precedent will be established, one that disrupts the normative prioritization of freedom of commerce, infusing life into the nomos of human rights that has languished in the shadow of Section 230. That case is still alive, notwithstanding recent filings by Backpage.com to stay that action, stating that it must deal with a new grand jury investigation currently underway before it can address the civil claims. As of this writing, the adult services sections on the Backpage.com website have been shuttered, and Backpage.com has posted a note under each adult services category heading that reads "Censored! The government has unconstitutionally censored this content," and that invites readers to "protect internet free speech" using the hashtags \#FREESPEECH \#BACKPAGE, emphasizing once more Backpage.com's commitment to the nomos of freedom of speech which actually acts as cover for unstated subtexts: freedom from costly litigation that hinders business operations; freedom of commerce and profit generation.

Returning to the discussion of slavery at the start of this work, acknowledging that concrete definitions and legal redress are challenging in an era in which slavery has been abolished legally but continues to thrive 
materially, we would do well to remember Orlando Patterson's (1982) description of slavery "as a special form of human parasitism" (p. 14) characterized by "direct and insidious violence...namelessness and invisibility...endless personal violation...and chronic inalienable dishonor" (p. 12). Stopping the parasitic flow of profits to Backpage.com executives from the bodies of those children trafficked on their website will entail review and, likely, amendment to Section 230 by Congress. But in the meantime, judges and courts must reject the neoliberal nomos that has pooled in the accumulation of precedent in this case, must transcend the current judicial "commitment to hierarchical ordering of authority first, and to interpretive integrity only later," (Cover, 1983, p. 58), and must restore protection of the gendered subjects seeking redress from the criminal harm of child sex trafficking to the center of future cases.

\section{Acknowledgements}

I gratefully acknowledge the Babson College Faculty Research Fund for its generous support of this work. A silent partner in this work is Director Mary Mazzio, whose film I Am Jane Doe (2017) inspired this essay. I Am Jane Doe brings to the screen the voices and perspectives of the "Jane Does" who, along with their families, fought the cases under analysis here. My thinking has benefited from the keen insights and guidance of David Nersessian and James Brewer Stewart, as well as the thoughtful and thorough reports of two anonymous readers, although any missteps here are, of course, entirely my own. I thank John Montgomery, Erik Bauer, and Faith Potter for their generosity of time and spirit in sharing ideas and information, and especially S.L. and Stephanie for their time, openness, and courage. My deepest gratitude to Mike Wager for his partnership in legal research, thinking, and understanding. I dedicate this work to MA., J.S., S.L., L.C., the Boston "Jane Does," and to the memory of Leah Evens.

\section{Conflict of Interests}

The author declares no conflict of interests.

\section{References}

Bernstein, E. (2007). Temporarily yours: Intimacy, authenticity, and the commerce of sex. Chicago: University of Chicago Press.

Communications Decency Act of 1996. 47 USC $\$ 230$.

Cover, R. M. (1975). Justice accused: Antislavery and judicial process. New Haven: Yale University Press.

Cover, R. M. (1983). The Supreme Court, 1982 termForeword: Nomos and narrative (Faculty Scholarship Series: Yale Law School Legal Scholarship Repository. Paper 2705. 4-68).

Cover, R. M. (1986). Violence and the word (Faculty Scholarship Series, Yale Law School Legal Scholarship Repository. Paper 2708. 1601-1629).
Daly, M. (2017). Backpage execs refuse to testify at sex trafficking hearing. Associated Press. Retrieved from http://bigstory.ap.org/article/0b33eb8343fb4e288a 9475dcfba5441c/backpage-execs-refuse-testify-sextrafficking-hearing

Dart v. Backpage.com, LLC., 2016137 S.Ct. 46. Transcript.

Dayan, J. (2011). The law is a white dog: How legal rituals make and unmake persons. Princeton, NJ: Princeton University Press.

Gira Grant, M. (2014). Playing the whore: The work of sex work. New York and London: Verso.

Historians Against Slavery. (n.d.). About us. Historians Against Slavery. Retrieved from http://www. historiansagainstslavery.org/main/about-us

International Labor Organization. (2012a). ILO global estimate of forced labor: Results and methodology. New York: International Labor Organization. Retrieved from file://C:/Users/egoldberg/Downloads/ ILO\%20global\%20estimate\%20of\%20forced\%20labo ur.pdf

International Labor Organization. (2012b). 21 million people are now victims of forced labour, ILO says. International Labor Organization. Retrieved from http://www.ilo.org/global/about-the-ilo/newsroom/ news/WCMS_181961/lang-it/index.htm

Jane Doe v. Backpage.com, 2016 WL 7047745. Opp. Brief. (Supreme Court of the United States, 2016).

Jane Doe v. Backpage.com, 2016 WL 7229219. Reply Brief of Petitioners. (Supreme Court of the United States, 2016).

Jane Doe v. Backpage.com, 2017817 F.3d 12 (1st Cir. 2016), No. 16-276, 2017 WL 69715. (US January 9, 2017).

J.S., S.L., and L.C. v. Village Voice Media Holdings, 2015 NO. 44920-0-II. (Supreme Court of the State of Washington, 2015).

Lee, C. (2016). Subverting the Communications Decency Act: J.S. v. Village Voice Media Holdings. The Circuit, Paper 85, 11-19.

Lloyd, R. (2011). Girls like us: Fighting for a world where girls are not for sale, an activist finds her calling and herself. New York: Harper Collins.

MA v. Village Voice Media Holdings, 2011809 F.Supp.2d 10. E.D. Mo.

Margolick, D. (1992, March 27). At the bar: Sustained by dictionaries, a judge rules that no word, or word play, is inadmissable. The New York Times. Retrieved from http://www.nytimes.com/1992/03/27/news/bar-sus tained-dictionaries-judge-rules-that-no-word-wordplay-inadmissible.html

Mazzio, M., Sokolow, A. (Producers), \& Mazzio, M. (Director). (2017). I Am Jane Doe. [Motion Picture]. United States: 50 Eggs, Inc.

Monbiot, G. (2016, April 15). Neoliberalism: The ideology at the root of all our problems. The Guardian. Retrieved from https://www.theguardian.com/books/ 2016/apr/15/neoliberalism-ideology-problem-george -monbiot 
Oxford English Dictionary online. (n.d.). Retrieved from https://en.oxforddictionaries.com

Pateman, C. (1988). The sexual contract. Palo Alto, CA: Stanford University Press.

Patterson, O. (1982). Slavery and social death: A comparative study. Cambridge, MA: Harvard University Press.

Quirk, J. (2011). The anti-slavery project: From the slave trade to human trafficking. Philadelphia: University of Pennsylvania Press.

Simpson, J., \& Speake, J. (Eds.). (2008). The Oxford dictionary of proverbs. Oxford: Oxford University Press.

William Wilberforce Trafficking Victims Protection Reauthorization Act. (2015). Public Law 110457. Retrieved from http://www.refworld.org/docid/49805 ae72.html

United Nations General Assembly. (2000a). Optional protocol to the convention on the rights of the child on the sale of children, child prostitution, and child pornography. Retrieved from http://www.ohchr.org/ EN/Professionallnterest/Pages/OPSCCRC.aspx

United Nations General Assembly. (2000b). Protocol to prevent, suppress and punish trafficking in persons especially women and children, supplementing the United Nations Convention against Transnational Organized Crime. Retrieved from http://www.ohchr. org/EN/Professionallnterest/Pages/ProtocolTraffick ingInPersons.aspx

United States Senate. (2017, January 10). Backpage.com's knowing facilitation of online sex trafficking. 2017. Retrieved from https://www.hsgac.senate. gov/subcommittees/investigations/reports

Woodhouse, B. B. (2008). Hidden in plain sight: The tragedy of children's rights from Ben Franklin to $\mathrm{Li}$ onel Tate. Princeton, NJ: Princeton University Press.

\section{About the Author}

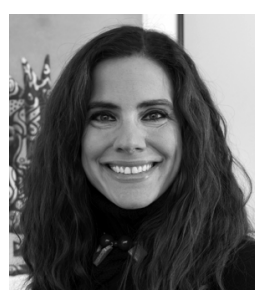

Elizabeth Swanson is a professor of literature and human rights at Babson College. Author of Beyond Terror: Gender, Narrative, Human Rights, she has edited several collections on the subject of literature and human rights, and has published extensively on gender, human rights, and modern slavery, as well as serving as Board Chair for the NGO Her Future Coalition, partnering with survivors of human trafficking to establish creative, dignified, and independent livelihood solutions. 